\title{
TIPE DATA REKAMAN
}

\author{
Muhajarul Zani \\ 185100028 \\ Fakultas Komputer \\ muhajarulzani.student@umitra.ac.id
}

\begin{abstract}
Tipe Data Rekaman

Laporan ini bertujuan untuk merancang dan membuat program yang dapat mendeklarasikan record/struct dari dalam program $\mathrm{C}++$. Perancangan dilakukan dengan membuat elemen-elemen/field dalam record. Sub-sub program ini berisi algoritma dan bahasa $\mathrm{C}++$ dalam mendukung berjalannya sebuah program.program ini juga bisa mendukung dan menjadi beberapa contoh untuk program lain, karna banyak para programer mengatakan program ini banyak di gunakan karna bentuk nya sederhana dan mudah di pahami. Dengan demikian pengembangan sistem program harus lebih diperhatikan terutama pada perguruan tinggi se- bagai pengembang teknologi dalam rangka memajukan teknologi dan bahasa pemrograman dalam negeri.
\end{abstract}

Kata Kunci : Tipe Data Rekaman

\section{A. PENDAHULUAN}

Berkembangnya zaman membuat banyak hal datang yang semakin membaik. Salah satu contohnya adalah kemajuan dalam bidang Ilmu Pengetahuan dan Teknologi (IPTEK). Berkembangnya ilmu pengetahuan diiringi dengan teknologi yang semakin canggih untuk melakukan riset-riset penelitian. Teknologi yang digunakan tidak hanya sekedar alat elektronik dan internet yang sudah tidak asing lagi bagi kita. Pengolahan data, penyimpanan dan pengarsipan data serta penyampaian informasi mulai berkembang lebih baik. Jika dahulu orang harus membukukannya dengan banyak kesalahan dalam pencatatan dan penghitungan, maka 
sekarang dengan adanya teknologi, semua pekerjaan dapat dilakukan satu kali tulis menggunakan applikasi komputer untuk mengerjakannya.

Perkembangan sistem informasi sekarang ini semakin pesat.Di era yang serba canggih ini, informasi merupakan kebutuhan penting. Pesatnya kebutuhan informasi tidak dapat dipisahkan dari perkembangan teknologi. Salah satu teknologi yang perkembangannya cukup pesat adalah internet. Internet mampu memberikan informasi tanpa batas yang sangat berguna bagi manusia. Perkembangan teknologi yang pesat saat ini mendorong perilaku manusia untuk cenderung bergeser dari cara-cara yang konvensional ke cara -cara yang lebih modern. Itulah sebabnya, manusia saat ini berlomba lomba untuk memanfaatkan dan memaksimalkan teknologiyang ada untuk membantu kehidupanya sehari hari. Salah satu teknologi yang berkembang cukup pesat adalah teknologi Multimedia, Teknologi Multimedia dapat dimanfaatkan dalam berbagai hal, salah satunya dimanfaatkan sebagai media pembelajaran. Sistem belajar mengajar di Indonesia saat ini sebagian besar masih menggunakan cara konvensional dalam penyampaian materi materinya.tetapi para masyarakat sekarang banyak menggunakan pemrograman misalnya $\mathrm{C}++$.Ini juga merupakan perkembangan teknologi sejak dahulu dan masih terus berkembang sampai sekarang bahkan pesat di kalangan pendidikan tetapi juga banyak yang tidak mengetahui mengenai program.

Berdasarkan latar belakang sebagaimana terurai diatas yang menjelaskan bagaimana teknologi digunakan dalam kegiatan bisnis, kantor, dan pendidikan. Dalam laporan yang berjudul "STRUCT/RECORD" ini ditujukan memberikan informasi bermanfaat tentang konsep dasar dan mendeklarasikan record dan semoga berguna bagi para generasi generasi yang akan datang

\section{B. PEMBAHASAN / STUDI KASUS}

Tipe data record adalah tipe data khusus yang komponennya terdiri dari berbagai jenis tipe data lain. Sebuah record berisi 
beberapa variabel lain yang

'dipaketkan'. Konsep struktur

data seperti ini sedikit mirip

dengan konsep object dalam

bahasa pemrograman modern

(walaupun di dalam pascal juga

terdapat konsep tentang

object).

\section{Record juga mirip}

dengan array, dimana kita bisa

membuat sebuah variabel yang

berisi berbagai element.

Perbedaannya, record bisa

menampung berbagai jenis tipe

data, tidak hanya 1 tipe data

seperti array.

\section{ID SECURITY}

QWTD4452377-ASP-5244107

\section{KESIMPULAN}

1. Record adalah tipe terstrukt ur yang terdiri atas sejumlah el emen yang tipenya tidak harus sama .Struct/Record adalah sekumpulan elemen data yang memiliki tipe dan panjang data yang berbeda-beda tapi memiliki nama yang sama.Struct/Record koleksi satuan data yang heterogen, yakni terdiri dari berbagai type: int, float, char, etc

2. Funsi record adalah menyimpan sejumlah data dengan nilai dan tipe data yang berbeda dalam satu wadah.Dan recodr jugamerupakan suatu tipe data terstruktur yang dapat menampung data field bertipe berbeda. Tipe ini dapat dipadukan dengan tipe data terstruktur lainnya seperti array.

3. Tipe data record adalah tipe data khusus yang komponennya terdiri dari berbagai jenis tipe data lain. Sebuah record berisi beberapa variabel lain yang 'dipaketkan'

4. Perbedaan record dan array Record semua elemenya harus bertipe berbeda antara satu sama lainnya, Array semua elemenya harus bertipe sama.

5. Ada 2 Model data berbasis $r$ ecord, model realisional dan model data realisional

6. Model data hirarki Adalah Hubungan antar data di representasikan dengan Record dan Link (Pointer).

7. Model data keterhubungan antar entitas yaitu Menjelaskan hubungan antar data dalam 
sistem basis data berdasarkan suatu presepsi bahwa real world terdiri dari obyek-obyek dasar yang mempunyai hubungan relasi antaraekoby-obyek tersebut 8. Model data berorientasi obyekModel basis data berorientasi objek adalah suatu model basis data, dimana data didefinisikan, disimpan, dan diakses menggunakan pemrograman berorientasi objek.

\section{E. DISKUSI}

DWI : APAKAH ARTIKEL INI SANGAT MEMBANTU ?

SAYA : KARNA ARTIKEL INI SUDAH CUKUP LENGKAP DAN SANGAT MEMBANTU.

DWI : OK KALO BEGITU SAYA AKAN BERTANYA TENTANG PENEGRTIAN TIPE DATA REKAMAN ?

SAYA ; TIPE DATA REKAMAN adalah tipe data khusus yang komponennya terdiri dari berbagai jenis tipe data lain. Sebuah record berisi beberapa variabel lain yang 'dipaketkan'.

\section{F. REFERENCE}

[1] O. M. Febriani and A. S. Putra, "Sistem Informasi Monitoring Inventori Barang Pada Balai Riset Standardisasi Industri Bandar Lampung," J. Inform., vol. 13, no. 1, pp. 90-98, 2014.

[2] A. S. Putra, "Paperplain: Execution Fundamental Create Application With Borland Delphi 7.0 University Of Mitra Indonesia," 2018.

[3] A. S. Putra, "2018 Artikel Struktur Data, Audit Dan Jaringan Komputer," 2018.

[4] A. S. Putra, "ALIAS MANAGER USED IN DATABASE DESKTOP STUDI CASE DB DEMOS."

[5] A. S. Putra, "COMPREHENSIVE SET OF PROFESSIONAL FOR DISTRIBUTE COMPUTING."

[6] A. S. Putra, "DATA ORIENTED RECOGNITION IN BORLAND DELPHI 7.0."

[7] A. S. Putra, "EMBARCADERO DELPHI XE 2 IN GPUPOWERED FIREMONKEY APPLICATION."

[8] A. S. Putra, "HAK ATAS KEKAYAAN INTELEKTUAL DALAM DUNIA TEKNOLOGY BERBASIS REVOLUSI INDUSTRI 4.0."

[9] A. S. Putra, "IMPLEMENTASI PERATURAN

PERUNDANGAN UU. NO 31 TAHUN 2000 TENTANG DESAIN INDUSTRI BERBASIS INFORMATION TECHNOLOGY." 
[10]
A.
S.
Putra,
"IMPLEMENTATION OF PARADOX DBASE."

A.

S.

Putra,

"IMPLEMENTATION OF

TRADE SECRET CASE

STUDY SAMSUNG MOBILE PHONE."

[12] A

A. S. Putra,

"IMPLEMENTATION

PATENT FOR APPLICATION

WEB BASED CASE STUDI

WWW. PUBLIKLAMPUNG. COM."

[13] A.

"IMPLEMENTATION

SYSTEM FIRST TO INVENT

IN DIGITALLY INDUSTRY."

[14] A. S. Putra, "MANUAL REPORT \& INTEGRATED DEVELOPMENT

ENVIRONMENT BORLAND DELPHI 7.0."

[15] A. S. Putra, "PATENT AS RELEVAN SUPPORT RESEARCH."

[16] A. S. Putra, "PATENT FOR RESEARCH STUDY CASE OF APPLE. Inc."

[17] A. S. Putra, "PATENT PROTECTION FOR APPLICATION INVENT."

[18] A. S. Putra, "QUICK REPORT IN PROGRAMMING."

[19] A. S. Putra, "REVIEW CIRCUIT LAYOUT COMPONENT

REQUIREMENT ON ASUS NOTEBOOK."

[20] A. S. Putra, "REVIEW TRADEMARK PATENT FOR INDUSTRIAL TECHNOLOGY BASED 4.0."

[21] A. S. Putra, "TOOLBAR
COMPONENT PALLETTE IN OBJECT ORIENTED

PROGRAMMING."

[22] A. S. Putra, "WORKING DIRECTORY SET FOR PARADOX 7."

[23] A. S. Putra, "ZQUERY CONNECTION

IMPLEMENTED

PROGRAMMING STUDI CASE PT. BANK BCA Tbk."

[24] A. S. Putra, D. R. Aryanti, and I. Hartati, "Metode SAW (Simple Additive Weighting) sebagai Sistem Pendukung Keputusan Guru Berprestasi (Studi Kasus: SMK Global Surya)," in Prosiding Seminar Nasional Darmajaya, 2018, vol. 1, no. 1, pp. 85-97.

[25] A. S. Putra and O. M. Febriani, "Knowledge Management Online Application in PDAM Lampung Province," in Prosiding International conference on Information Technology and Business (ICITB), 2018, pp. 181-187.

[26] A. S. Putra, O. M. Febriani, and B. Bachry, "Implementasi Genetic Fuzzy System Untuk Mengidentifikasi Hasil Curian Kendaraan Bermotor Di Polda Lampung," SIMADA (Jurnal Sist. Inf. dan Manaj. Basis Data), vol. 1, no. 1, pp. 21-30, 2018.

[27] A. S. Putra, H. Sukri, and K. Zuhri, "Sistem Monitoring Realtime Jaringan Irigasi Desa (JIDES) Dengan Konsep Jaringan Sensor Nirkabel," IJEIS (Indonesian J. Electron. Instrum. Syst., vol. 8, no. 2, pp. 221-232. 
[28] D. P. Sari, O. M. Febriani, and A. S. Putra, "Perancangan Sistem Informasi SDM Berprestasi pada SD Global Surya," in Prosiding Seminar Nasional Darmajaya, 2018, vol. 1, no. 1, pp. 289-294. 